\title{
A systematic review of the clinical effectiveness of Cochlear Implant Surgery in paediatric and adult patients
}

\author{
Abdullah Musleh ${ }^{1}$ \\ ${ }^{1}$ King Khalid University
}

August 17, 2020

\begin{abstract}
Background and Objective: Hearing loss, also termed as hearing impairment, is an ailment where hearing is impaired partially or fully. About 1 in 8 people suffer from hearing loss worldwide. The main aim of this current systematic review was to analyse the clinical effectiveness of CI surgery in paediatric and adult patients.
\end{abstract}

\section{Hosted file}

manuscript V3.docx available at https://authorea.com/users/351363/articles/476010a-systematic-review-of-the-clinical-effectiveness-of-cochlear-implant-surgery-inpaediatric-and-adult-patients 